\title{
Adsorption of Lead Content in Leachate of Sukawinatan Landfill Using Solid Waste of Tofu
}

\author{
Sri Hartati ${ }^{1 * *}$, Dedik Budianta ${ }^{2}$, Hermansyah $^{3}$ \\ ${ }^{1}$ Department of Natural Resources Management, Faculty of Environmental Management, Graduate Program, Sriwijaya University \\ ${ }^{2}$ Faculty of Agriculture, Department of Soil Sciences, Sriwijaya University \\ ${ }^{3}$ Faculty of Mathematics and Natural Sciences, Department of Chemistry, Sriwijaya University Jl Padang Selasa, Bukit Besar \\ Palembang 30129. Indonesia \\ *Corresponding author.email: hello2srimarch@gmail.com
}

Article history

\begin{tabular}{llll} 
Received & Received in revised form & Accepted & Available online \\
1 July 2016 & 23 July 2016 & 1 August 2016 & 15 August 2016 \\
\hline
\end{tabular}

\begin{abstract}
A study on the adsorption of lead content in the leachate from the landfill by using solid waste of tofu. This study assed the effects of weight of the solid waste of tofu and the contact time on the efficiency of the Pb adsorption. The sample used in this study was artificial sample of a solution of $\mathrm{Pb}$ metal ion and the sample of the leachate of the landfill waste. The study was carried out with a batch system, with the variables of weight of waste of tofu of 0.5 ; $1.0 ; 1.5 \mathrm{~g}$. While the variables of the contact time were $0,30,60,90,120$ and 150 minutes. To determine the optimum conditions, the waste of tofu was dissolved in $50 \mathrm{~mL}$ of $\mathrm{Pb}$ metal ion solution with a concentration of $20.27 \mathrm{mg} / \mathrm{L}$ and stirred with a shaker for 30 minutes at a speed of $180 \mathrm{rpm}$. The same thing was done by varying the contact time. When the optimum condition was obtained, it was applied with varying concentrations of $\mathrm{Pb}$ metal ion solution and garbage landfill leachate. The initial and the final levels of the $\mathrm{Pb}$ metal ion solution were analyzed by using the Atomic Adsorption Spectroscopy (AAS). The initial and the final results of the heavy metals were analyzed for disclosing the adsorption efficiency. To reveal the effects of the weight of the waste of tofu and the contact time, the data were analyzed with graphs. The waste of tofu with a weight of $1.5 \mathrm{~g}$ and a contact time of 90 minutes, had an adsorption efficiency of $97.68 \%$ at a concentration of $20.27 \mathrm{mg} / \mathrm{L}$ for $\mathrm{Pb}$ ion solution and $28.57 \%$ for the leachate from the landfill waste in $100 \mathrm{~mL}$ of leachate.
\end{abstract}

Keywords: solid waste of tofu, adsorbent, adsorption, lead, leachate

\begin{abstract}
Abstrak (Indonesian): Telah dilakukan penelitian tentang adsorpsi kadar timbal dalam lindi dari sampah TPA dengan menggunakan limbah padat tahu. Penelitian ini akan mengkaji pengaruh berat ampas tahu dan waktu kontak terhadap efisiensi adsorpsi $\mathrm{Pb}$. Sampel yang digunakan dalam penelitian ini adalah sampel buatan dari larutan ion logam $\mathrm{Pb}$ dan sampel dari lindi sampah TPA. Penelitian dilakukan dengan sistem batch, dengan variabel berat ampas tahu 0,$5 ; 1,0 ; 1,5$ g. Sedangkan variabel waktu kontak adalah 0, 30, 60, 90, 120 dan 150 menit. Untuk menentukan kondisi optimum, variabel berat ampas tahu dilarutkan dalam $50 \mathrm{ml}$ larutan ion logam Pb dengan konsentrasi 20,27 $\mathrm{mg} / \mathrm{L}$ lalu di aduk dengan shaker selama 30 menit dengan kecepatan 180 r.p.m. Hal yang sama dilakukan dengan variasi waktu kontak, setelah diperoleh kondisi optimum diaplikasikan dengan variasi konsentrasi larutan ion $\mathrm{Pb}$ dan lindi sampah TPA. Kadar larutan ion logam $\mathrm{Pb}$ awal dan akhir dianalisis dengan menggunakan Spektrofotometer Serapan Atom. Hasil awal dan akhir logam berat dianalisis untuk diketahui efisiensi adsorpsinya. Untuk mengetahui pengaruh berat ampas tahu dan waktu kontak data dianalisis dengan grafik. Ampas tahu dengan berat 1,5 g dan waktu kontak 90 menit, efisiensi adsorpsinya sebesar 97,68\% pada konsentrasi 20,27 mg/L untuk larutan ion $\mathrm{Pb}$ dan 28,57\% untuk lindi dari sampah TPA dalam $100 \mathrm{~mL}$ lindi.
\end{abstract}

Kata kunci: limbah padat tahu, adsorben, adsorpsi, timbal, lindi.

\section{Introduction}

At present the city of Palembang is faced with the problem of handling domestic waste which is increasingly accumulating. The city's garbage being accommodated in the Final Disposal Area (FDA) will undergo decomposition. The decomposition process leads to the physical, chemical and biological changes simultaneously. The Problems will arise when rainwater and surface water seeps into the trash heap and causes the seepage of the liquid called leachate. This fluid can contaminate surface water and underground water.

The leachate from the landfill (FDA) is a contaminant that can damage the health of humans, pollute the environment and aquatic biota, because the leachate 
contains a variety of organic and inorganic chemical compounds and a number of pathogenic bacteria [1].

Although various efforts have been made to eliminate the ions / heavy metal compounds from the industrial waste for decades, but the effectiveness of their physical and chemical processes is still limited [2]. The conventional method usually done is by way of depositing the metals in the sediment pond. Furthermore, the heavy metals are removed by means of extraction and electro reclamation [3]. Out of cost considerations, some innovative methods were developed. The methods include ultrafiltration with polymer [4] or by adsorption of biopolymers [5,6], filtration adsorption by using sand [6,7], adsorption by using magnetic iron oxide [8] and biosorption [9].

Biosorption is a method of taking / binding of metal ions by adsorption by using biological materials. Biosorption has been widely demonstrated as an alternative method for removing heavy metal compounds from contaminated waters, not only because it is inexpensive but also because it is safe for the environment [10].

Cost consideration is an important parameter in the sorbent materials. A Sorbent is considered "cheap" when it is obtained through simple processing, available in abundance both naturally and as a byproduct / waste of industrial activity, has a high adsorption capacity [6] and allows for renewal [11]. Relatively cheap biological material has shown its potential in removing these ions. Some byproducts of industry and agricultural products have potential to be used as a cheap adsorber.

The waste of tofu is a biomaterial produced from tofu manufacturing. This biomaterial potentially will cause environmental problems if it is not managed properly. But this waste contains a protein comprising of amino acids capable of forming a zwitterionic ions (doubly charged), a protein that has active sides (groups) such as (-NH2) and $\mathrm{OH}$ and allows -SH to bind to metal ions or other compounds. Besides it also contains substances that are not soluble in water such as fat, starch and sugar. Time, the weight of the adsorbent, and $\mathrm{Pb}$ concentration are the factors that affect the adsorption. Therefore, these variables are used in this study.

\section{Experimental Sections}

The equipment used in this study were AA-7000 Atomic Adsorption Spectroscopy from Shimadzu, oven, analytical balance, shaking tool/shaker, erlenmeyer, beaker glass, flask, Whatman filter paper No. 42, desiccator, iron clamp, porcelain crucible, titrimetric pipette, $\mathrm{pH}$ meter, glass bottles to contain leachate.

The materials used in this study were Sukawinatan's landfill leachate water, $\mathrm{HNO}_{3} 65 \%, \mathrm{~Pb}\left(\mathrm{NO}_{3}\right)_{2}$, distilled water, solid waste of tofu at Kemang Manis.

This study was carried out with a laboratory scale experimental method. This study began with the manufacturing of adsorbent from waste of tofu by putting $0.5 \mathrm{~kg}$ of wet tofu waste on an oven for 5 hours at a temperature of $105^{\circ} \mathrm{C}$. Then dried tofu was obtained which was then pulverized and sieved through a sieve to obtain dried tofu with a size of $\pm 250 \mu \mathrm{m}$. Furthermore, the process of adsorption between waste of tofu and lead metal ion solution. The variable process was the weight variation of $0.5 ; 1.0$ up to $1.5 \mathrm{~g}$ with $50 \mathrm{~mL}$ volumes of waste for each sample and a stirring speed of $180 \mathrm{rpm}$. The contact time of adsorption process was $0 ; 30 ; 60 ; 90$; 120; and 150 minutes with $0,5 \mathrm{~g}$ waste of tofu, $50 \mathrm{~mL}$ volumes of waste for each sample and a stirring speed of $180 \mathrm{rpm}$. For adsorption isotherms the variation of lead metal ion concentration was $0 ; 20 ; 40 ; 60 ; 80$ and 100 ppm in an optimum condition. Furthermore, it was applied by using the leachate from the Sukawinatan's landfill based on the optimum condition from the previous stage.

The metal uptake, $\mathrm{q}(\mathrm{mg} / \mathrm{g})$ expressed in the equation:

$$
Q=\frac{\left(C_{0}-C_{e}\right) V}{m}
$$

where $\mathrm{C} 0$ and $\mathrm{Ce}$ are the initial and final metal ion concentrations (in $\mathrm{mg} / \mathrm{L}$ ) respectively, $\mathrm{V}$ is the volume of the solution (in $\mathrm{mL}$ ) and $\mathrm{m}$ is waste of tofu weight (in g) in dry form.

\subsection{Freundlich isotherm}

In 1906, Freundlich introduced adsorption isotherm equation. This empirical model can be applied to an adsorption system which is not ideal on heterogeneous surfaces such as on the adsorption by double surfaces and is expressed in the equation below:

$$
q_{e}=K_{f} C_{e}{ }^{1 / n}
$$

This equation can be used in a linear form by changing the above equation to become:

$$
\log _{10} q_{e}=\log _{10} K_{f}+1 / n \log _{10} C_{e}
$$

in which qe is the number of ions adsorbed $(\mathrm{mg} / \mathrm{g}), \mathrm{Ce}$ is the equilibrium concentration of the solution $(\mathrm{mg} / \mathrm{L}), \mathrm{Kf}$ and $\mathrm{n}$ are the equilibrium constants [12].

\subsection{Langmuir isotherm}

In 1916 Langmuir developed the theory of equilibrium isotherm to the amount of gas adsorbed on the surface. The Langmuir model is very good and can be applied to the adsorption isotherm. Langmuir isotherm formula is expressed as follows:

$$
q_{e}=\frac{q_{\max } b C_{e}}{1+b C_{e}}
$$

The above equation can be changed into the following linear equation: 


$$
\frac{C_{e}}{q_{e}}=\frac{1}{q_{\max } b}+\frac{C_{e}}{q_{\max }}
$$

in which $\mathrm{Ce}$ is the equilibrium concentration of solution $(\mathrm{mg} / \mathrm{L})$, qe is the amount of ions adsorbed $(\mathrm{mg} / \mathrm{g})$, qmax is the amount of maximum adsorption surface $(\mathrm{mg} / \mathrm{g}), \mathrm{b}$ is the equilibrium constant of adsorption [12].

Langmuir model assumes that the capture metal ions occurs on the homogeneous surface with a single layer adsorption without interaction among the ions adsorbed.

\section{Result and Discussion}

\subsection{The characteristics of the leachate of Sukawinatan's landfill}

Leachate contains organic materials, inorganic materials, and pathogenic bacteria. The leachate in this study has the characteristics of blackish brown and a pungent odor. The results of the study reveal the quality of the leachate as shown in Table 1.

\begin{tabular}{|c|c|c|c|c|c|}
\hline No. & $\begin{array}{c}\text { Testing } \\
\text { Parameter }\end{array}$ & Unit & $\begin{array}{l}\text { Testing } \\
\text { Results }\end{array}$ & $\begin{array}{c}\text { Quality } \\
\text { Standard }\end{array}$ & Notes \\
\hline 1. & $\mathrm{~Pb}$ & $\mathrm{mg} / \mathrm{L}$ & 0,18 & 0,1 & Over TLV \\
\hline 2. & $\mathrm{BOD}_{5}$ & $\mathrm{mg} / \mathrm{L}$ & 266,95 & 50 & Over TLV \\
\hline 3. & COD & $\mathrm{mg} / \mathrm{L}$ & 2320,6 & 100 & Over TLV \\
\hline 4. & TSS & $\mathrm{mg} / \mathrm{L}$ & 239 & 200 & Over TLV \\
\hline 5. & DO & $\mathrm{mg} / \mathrm{L}$ & 2,1 & 6 & No More Than TLV \\
\hline 6. & $\mathrm{NO}_{2}$ & $\mathrm{mg} / \mathrm{L}$ & 0,27 & 1 & No More Than TLV \\
\hline 7. & $\mathrm{pH}$ & - & 8,1 & $6,0-9,0$ & No More Than TLV \\
\hline 8. & Temperature & ${ }^{0} \mathrm{C}$ & 24,9 & 38 & No More Than TLV \\
\hline
\end{tabular}

The data in Table 1 show that four parameters, namely $\mathrm{DO}, \mathrm{NO}_{2}, \mathrm{pH}$ and temperature do not exceed the threshold limit value (TLV), while the other four parameters, namely $\mathrm{Pb}, \mathrm{BOD}_{5}, \mathrm{COD}$, TSS exceed the threshold limit value (TLV) as specified by the Minister of State for the Environmental Matters Number 51 of the Year 1995 regarding The Quality Standards of Industrial Wastewater, so those that exceed the threshold limit value (TLV) need further processing before the leachate is allowed to enter the surrounding waters.

\subsection{The characteristics of the waste of tofu}

The data in Table 2 show that the waste of tofu taken from the area of Kemang Manis in Palembang City has the protein content fairly high at $18.91 \%$. The protein has a power uptake of amino acids that form a zwitterionic ions (doubly charged) and can bind $\mathrm{Pb}^{2+}$. The $\mathrm{pH}$ value is 5.17 and the moisture content is high at $83.31 \%$.

Table 2. The Results of Analysis of the Dried Waste of Tofu

\begin{tabular}{clcc}
\hline No. & \multicolumn{1}{c}{ Parameter } & Unit & Results \\
\hline 1. & Protein & $\%$ & 18.91 \\
2. & pH & - & 5.17 \\
3. & Moisture Content & $\%$ & 83.31 \\
\hline
\end{tabular}

\subsection{The effects of the weight of tofu waste}

The results of the study conducted on the basis of the weight tofu waste of $0.5 ; 1.0 ; 1.5 \mathrm{~g}$ are presented in the curve below: the weight of tofu with the highest efficiency of adsorption of the metal ions of lead is 1.5 g.

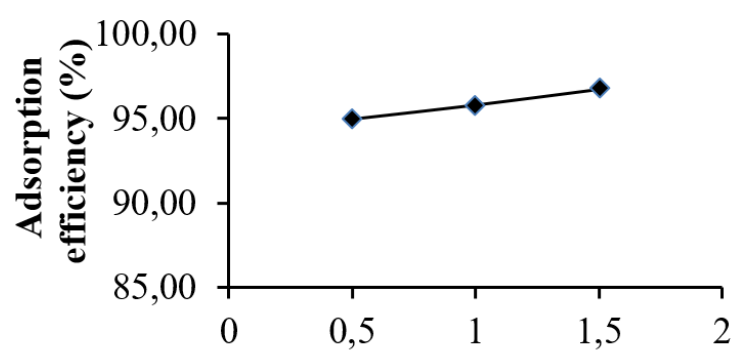

The weight of tofu waste (g)

Figure 1. The effects of the weight of tofu waste on the adsorption of the $\mathrm{Pb}$ metal ion solution

The data in Figure 1 show that the heavier the tofu waste is used, the greater the efficiency of absorption of the metal ions. For the weight of $0.5 \mathrm{~g}$ of tofu waste, the adsorption efficiency is $94.97 \%$. When the weight of tofu waste is increased to $1.5 \mathrm{~g}$, the adsorption efficiency increases to $96.74 \%$. The increase of the weight of tofu waste is proportional with the increasing number of particles and the surface area of tofu waste, causing an increase in the active site of adsorption and adsorption efficiency. The adsorption process takes place on the surface layer of cells that have sites that are oppositely charged metal ions so that the interaction is passive and relatively fast [13]. The particles of adsorbent have an active side with a negative charge that will interact with positively charged metal ions [14]. By decreasing the particle size of the adsorbent, the more extensive the surface becomes, and the higher the adsorption efficiency becomes.

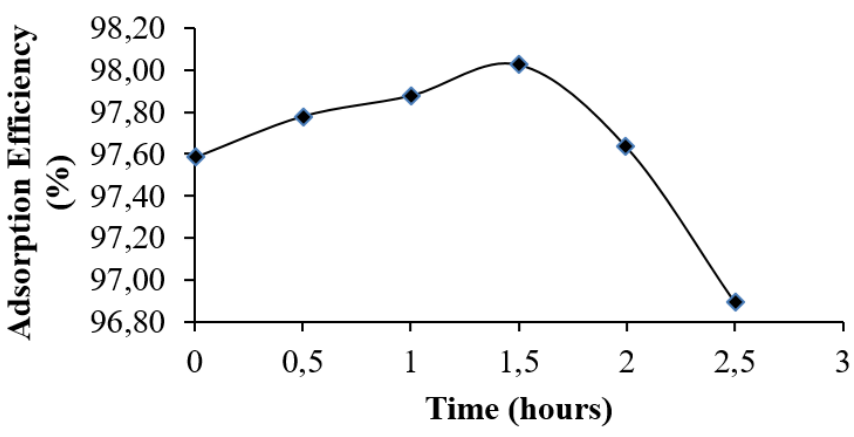

Figure 2. The effects of contact time (hours) on the adsorption of the $\mathrm{Pb}$ metal ion solution

\subsection{The effects of contact time}

The results of the study on the basis of the contact time of $0 ; 0.5 ; 1 ; 1.5 ; 2 ; 2.5$ hours are presented in the curve below shown in Figure 2: the adsorption efficiency increases with the length of the contact time and the optimum contact time is achieved in 1.5 hours, then decreases. Before reaching 1.5 hours the likelihood is 
that the active group of tofu waste has not reached saturation, meaning that there are still many active groups that have not been used to adsorb $\mathrm{Pb}$. At 1.5 hours, the active group that is used to adsorb $\mathrm{Pb}$ is in the optimum amount that is equal to $98.03 \%$. After 1.5 hours, the adsorption decreases, this is because the active groups that exist in the adsorbent getting saturated by lead and the lead concentration in the solution is getting smaller in amount.

\subsection{The capacity of adsorption of $P b$ metal ion by the waste of tofu}

Biosorption isotherm is a relationship of equilibrium concentration of solute in a solution and solute equilibrium in biosorbent at a constant temperature. The type of adsorption isotherm can be used to study the mechanism of adsorption. The solid-liquid phase adsorption generally adopted Freundlich and Langmuir isotherm types [15]. The bonds between the molecules of adsorbate and adsorbent surface may occur by means of physisorption and chemisorption.

Table 3. Isotherm Adsorption of $\mathrm{Pb}$ Metal Ion Solution

\begin{tabular}{ccccc}
\hline $\begin{array}{c}\text { Equilibrium } \\
\text { Concentration (mg/L) } \\
\mathbf{C e}\end{array}$ & $\begin{array}{c}\text { Capacity of } \\
\text { Adsorption (mg/g) } \\
\mathbf{q e}\end{array}$ & Ce/qe & Log Ce & Log qe \\
\hline 0.47 & 0.66 & 0.71 & -0.33 & -0.18 \\
1.06 & 1.24 & 0.86 & 0.03 & 0.09 \\
1.47 & 1.92 & 0.77 & 0.17 & 0.28 \\
2.17 & 2.59 & 0.84 & 0.34 & 0.41 \\
3.02 & 3.22 & 0.94 & 0.48 & 0.51 \\
\hline
\end{tabular}

In the determination of the type of isotherm the adsorbent used was at the optimum condition. Isotherm Adsorption of $\mathrm{Pb}$ Metal Ion Solution is shown in Table 3 and the isotherm adsorption of tofu waste of Langmuir and Freundlich type is shown in Figures 3 and 4. Freundlich isotherm showed higher linearity at $99.6 \%$ compared with the Langmuir isotherm at $69.5 \%$ with a value of $b=$ 0.10 . The value of the constant of $\mathrm{K} f=1.29$ and $\mathrm{n}=1.15$.

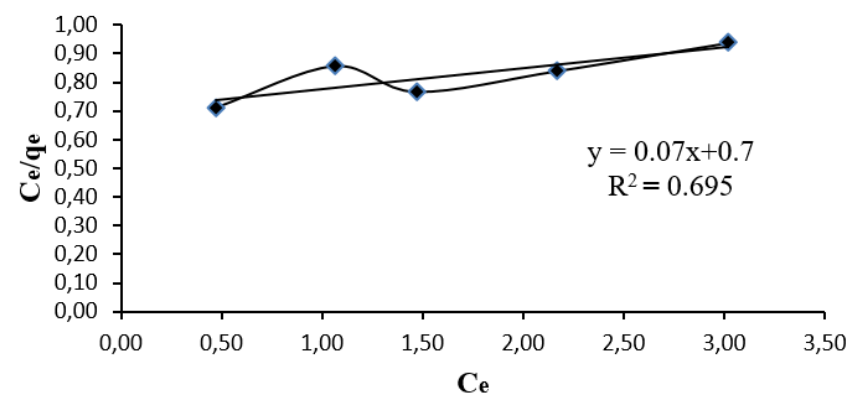

Figure 3. Langmuir's isotherm of the $\mathrm{Pb}$ metal ion biosorption by the biomass of tofu waste

The adsorption of $\mathrm{Pb}$ metal ion by tofu waste is considered to follow Freundlich isotherm type. If the type of isotherm adopted is Langmuir isotherm, the adsorption which takes place is chemisorption monolayer. If isotherm adopted is the Freundlich isotherm, adsorption occurs is physisorption multilayered [16]. The mechanism of physisorption allows the bond between metal ions contained in the solution or waste, in addition to their ties with the adsorbent. Both bonds are only bound by van der Waals forces so that the bond between the adsorbate and adsorbent is weak. This allows the adsorbate to move freely until multi-layer adsorption process takes place.

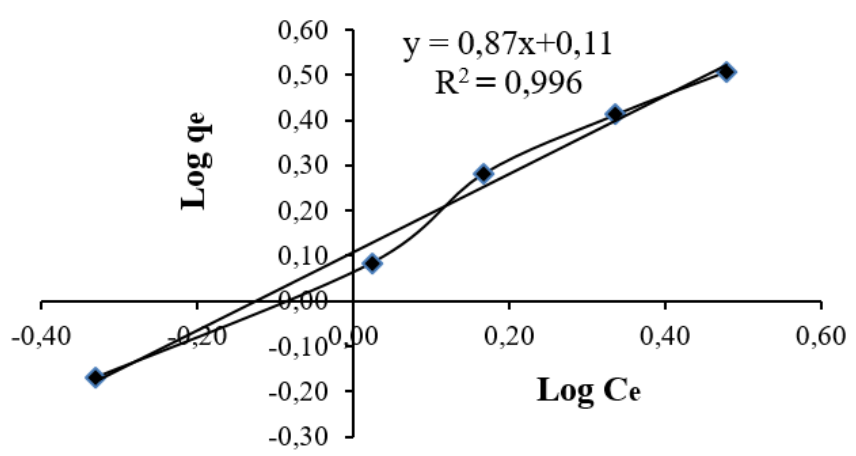

Figure 4. Freundlich isotherm of biosorption of $\mathrm{Pb}$ metal ions by the biomass of tofu waste.

\subsection{The application of tofu waste on $\mathrm{Pb}$ in the leachate of Sukawinatan's Landfill}

The lead $(\mathrm{Pb})$ in the leachate of the landfill tested in this study had an initial $\mathrm{Pb}$ value before treatment of 0.14 $\mathrm{mg} / \mathrm{L}$ in $100 \mathrm{~mL}$ of leachate waste and a final $\mathrm{Pb}$ value after treatment with tofu waste weighing $1.5 \mathrm{~g}$ with the contact time of $1.5 \mathrm{~h}$ has a value of $0.10 \mathrm{mg} / \mathrm{L}$. The decrease of the $\mathrm{Pb}$ level reached $28.57 \%$ and an adsorption power of $0.003 \mathrm{mg} / \mathrm{g}$. The testing of the existence of $\mathrm{Pb}$ contained in leachate used a testing method of $\mathrm{Pb}$ level with Atomic Absorption Spectrophotometer by means of reduction. The results show that the adsorption of the lead in the leachate provides good absorption efficiency. This shows that tofu waste with the optimum condition is an excellent adsorbent for use as an absorbent material.

The value of the adsorption capacity obtained is quite good. The adsorptive capacity depends on the characteristics of the tofu waste such as its texture (surface area, pore size distribution), surface chemistry (functional groups on the surface) and protein content. It also relies on the adsorption characteristics: molecular weight, polarity, pKa, molecular size, and functional groups. The condition of the solution is also influential such as: $\mathrm{pH}$, concentration and the adsorption of the other substances [17].

\section{Conclusion}

Based on the results of this study it can be concluded that the greater the $\mathrm{x}$-concentration of $\mathrm{Pb}$ metal ions, the greater the mass of $\mathrm{Pb}$ metal ions adsorbed by the waste of tofu. The optimum adsorption is at a concentration of $20.27 \mathrm{mg} / \mathrm{L}$ that is equal to $7.68 \%$ with the weight of tofu waste of $1.5 \mathrm{~g}$, the stirring speed of $180 \mathrm{rpm}$, and a 
contact time of 1.5 hours. The adsorption of $\mathrm{Pb}$ metal ions by using tofu waste follows isotherm adsorption of Freundlich with $\mathrm{R}^{2}$ value of 0.996 . Its application to the leachate may decrease $\mathrm{Pb}$ metal by $28.57 \%$ and absorption capacity of $0.003 \mathrm{mg} / \mathrm{g}$ in $100 \mathrm{~mL}$ of leachate which is based on the optimum conditions obtained from the previous treatment.

\section{References}

[1] S. P. Ganefati, dan J. P. Susanto. "Pengolahan Lindi (Leachate) dengan Model Coagulation - Biofilter Unaerobic.” Jurnal Teknologi Lingkungan, vol. 9, pp. 191-196, 2008.

[2] D. Kratochvil, and B. Volesky. "Biosorption of $\mathrm{Cu}$ from Ferruginous Wastewater by Algal Biomass." Journal of Water Research, vol. 32, pp. 2760-2768, 1998.

[3] S. Babel, and D. Dacera. "Heavy Metal Removal from Contaminated Slugde for Land Application". Journal of Waste Management, vol. 26, pp. 9881004, 2005.

[4] E. Guibal. "Interactions of Metal Ions with ChitosanBased Sorbents." Journal of Separation and Purification Technology, vol. 38, pp. 43-74, 2004.

[5] L. K. Jang, D. Nguyen, and G. G. Geese. "Effect of $\mathrm{pH}$ on the Absorption of $\mathrm{Cu}(\mathrm{II})$ by Alginate Gel." Journal of Water Research, vol. 29, pp. 315-321, 1995.

[6] S. E. Bailey, J. O. Trudy, R. M. Bricka, and D. D. Adrian. "A Review of Potentially Low-Cost Sorbents For Heavy Metals." Journal of Water Research, vol. 33, pp. 2469-2479, 1999.

[7] M. M. Benjamin, R. S. Sletten, R. P. Bailey, and T. Bennet. "Sorption and Filtration of Metal using Iron-Oxide-Coated Sand". Journal of Water Research, vol. 30, pp. 2609-2620, 1996.

[8] W. Y. Chen, P. R. Anderson and T. M. Holsen. "Recovery and Recycle of Metals from Wastewater with a Magnetite-Based Adsorption Prosess." Research Journal of the Water Pollution, vol. 63, pp. 958-964, 1991.

[9] B. Volesky. Biosorption of Heavy Metal, Florida, Boca Raton: CRC Press, 1990, pp. 396.

[10] F. Veglio and F. Beolchini. "Removal of Metals by Biosorption." Research Paper Hidrometallurgy, vol. 44, pp. 301-316, 1997.

[11] S. S. Ahluwalia and D. Goyal. "Microbial and Plant Derived Biomass for Removal of Heavy Metals from Wastewater." Journal of Bioresource Technology, vol. 98, pp. 2243-2257, 2007.

[12] X. Wang and Y. Qin. "Equilibrium Sorption Isotherms for of $\mathrm{Cu}^{2+}$ on Rice Bran." Journal of Process Biochemistry, vol. 40, pp. 677-680, 2005.

[13] M. N. Hughes dan R. K. Poole. Metals and Microorganism, London: Chapman and Hall, 1984.

[14] A. H. A. Mahvi, D. Naghipour, F. Vaezi and S. Nazmara. "Teawaste as an Adsorbent for Heavy
Metal Removal from Industrial Wastewater." American Journal of Applied Science, vol. 2, pp. 372-375, 2005.

[15] P. W. Atkins. Kimia Fisika 2, Jakarta : Erlangga, 1999.

[16] I. T. Anggraningrum. Model Adsorpsi Ion Kompleks Koordinasi Nikel (II) pada Permukaan Alumina, Jakarta: Tesis, Magister Sains Ilmu Kimia Universitas Indonesia, 1996.

[17] F. Villacarias. "Adsorption of Simple Aromatic Compound on Activated Carbon." Journal of Colloid and Interface Science, vol. 293, pp. 128136. 2005. 